\title{
Susceptibility and compatibility of Biomphalaria tenagophila from the Río de la Plata basin with Schistosoma mansoni from Brazil
}

\author{
Carlos Edgardo Borda/ ${ }^{+}$, María Josefa F Rea \\ Centro Nacional de Parasitología y Enfermedades Tropicales, Facultad de Medicina, \\ Universidad Nacional del Nordeste, 3400 Corrientes, Argentina
}

\begin{abstract}
Schistosomiasis has expanded to southern parts of Brazil. Between 2005-2007 the dispersion and the proliferation of Biomphalaria tenagophila was verified in the province of Corrientes near the Brazilian border. In order to study the possibility that schistosomiasis might spread into the basins of the Paraná and Uruguay Rivers, 440 B. tenagophila collected from 10 populations groups were experimentally exposed to infection with Schistosoma mansoni of the SJ strain. Snails from five localities were susceptible. Frandsen's index (TCP/100) shows that those snails from Mirungá (11\%), Aguacerito (2\%) and Curupicay (2\%) were Class I and not very compatible. Meanwhile, snails from Copra (6\%) and Pay-Ubre (22\%), in the Paraná River basin, were Class II and poorly compatible.
\end{abstract}

Key words: compatibility - Biomphalaria tenagophila - Río de la Plata basin - Schistosoma mansoni

Biomphalaria glabrata and Biomphalaria tenagophila snails are the natural intermediate hosts of Schistosoma mansoni in the Brazilian states of São Paulo (SP), Paraná, Santa Catarina and Rio Grande do Sul (RS). In the last state, the most southern part is located in Esteio, a locality near Porto Alegre (Carvalho et al. 1998, Graeff-Teixeira et al. 1999, 2004).

B. tenagophila populations from Ayolas (Paraguay) in the Paraná River basin and Fuente Salto (Uruguay), in the Uruguay River basin, behave as potential vectors in the experimental infection with the $\mathrm{SJ}_{2}$ strain of $S$. mansoni (Borda \& Rea 1997).

Similar results were obtained with snails of that same species collected from five localities in Argentina (Posadas, Berón de Astrada, Rincón de Vences, Maloyas and Goya) and one in Paraguay (Encarnación) (Borda \& Rea 2007).

The Uruguay River forms a natural border between Argentina and Brazil. Numerous small dams have been built for the cultivation of rice in the eastern region of the province of Corrientes in the basin of the Uruguay River.

The objective of the present paper is to increase knowledge about susceptibility and compatibility of allopatric populations of $B$. tenagophila from the Río de la Plata basin.

\section{MATERIALS AND METHODS}

Malacological surveys were undertaken in 10 localities in the province of Corrientes $\left(27^{\circ} 50^{\prime} \mathrm{N} 52^{\circ} 50^{\prime} \mathrm{W}\right)$ (Figure). The Miriñay River is the most important in this region and ultimately drains into the Uruguay River.

Financial support: Secretaría General de Ciencia y Técnica/UNNE, ICAA + Corresponding author: cborda@med.unne.edu.ar Received 26 February 2009

Accepted 13 November 2009
This region has a humid subtropical climate and no defined dry season.

Samples of snails were collected from 10 places in the Paraná and Uruguay River basins. Natural infection was not detected in any of the collected snails. These snails were identified as B. tenagophila using techniques detailed previously (Borda \& Rea 1997).

A total of 440 B. tenagophila specimens $(4-8 \mathrm{~mm})$ were individually exposed to 10 miracidia of $S$. mansoni $\mathrm{SJ}_{2}$ strain from São José dos Campos, SP, Brazil. This strain is more adapted to B. tenagophila and it is routinely maintained at the Cenpetrop laboratories by passage through sympatric $B$. tenagophila and hamsters (Mesocricetus auratus) or albino Swiss mice. The procedures for exposure of snails to miracidia, the duration of precercarial period and the infection index were previously described by Paraense and Corrêa (1989).

The snails were descendants of specimens obtained from nine places in the Uruguay basin: Itá-Cabó, Mirungá 1, Mirungá 2, Aguacerito, Curupicay, Copra, San Celestino, Yuquerí and Márquez and one from the Paraná basin, Pay-Ubre.

After 28 days, the molluscs from each group were individually exposed to artificial light $28-30^{\circ} \mathrm{C}$ (Standen 1952) and examined under stereomicroscope, in order to detect the snails, which were shedding cercariae. Snails were observed daily and, if any specimen happened to die, it was dissected and examined for the presence of the various developmental stages of Schistosoma.

To determine the degree of compatibility between the parasite and the snail, each infected snail was kept separately in an aquarium and was exposed to light for three days of the week between 9 am-5 pm. The cercariae were then counted using a quantitative method proposed by Frandsen $(1979 a, b)$. The emission of cercariae was followed until death in all the positive specimens.

The specimens that survived for 60 days after exposure without shedding cercariae were examined after being subjected to squeezing between glass slides. To 


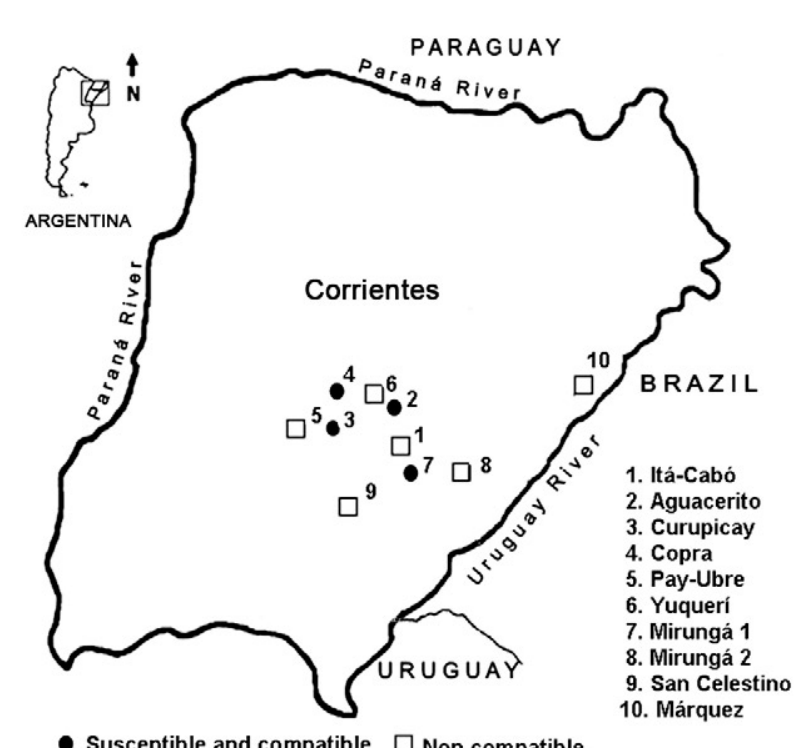

Situation of localitıes were Biomphalaria tenagophila were collected in the province of Corrientes, Argentina.

compare infection rates, 100 sympatric B. tenagophila were each exposed to 10 miracidia and subjected to the same process as described above.

\section{RESULTS}

The infection index for $B$. tenagophila varied widely according to the snail populations. Of the $440 \mathrm{~B}$. tenagophila exposed to the $S$. mansoni's $\mathrm{SJ}_{2}$ strain 26 became infected $(5.9 \%)$. While none of the specimens from Yuquerí, Itá-Cabó, Mirungá 2, San Celestino and Márquez became infected, the snails from five other localities were susceptible with an infection rate between 2-22\% (Table). The mortality index in the precercarial period was $17.72 \%$ and none showed infection at the time of dissection. The mortality index was higher in the insusceptible snails from Itá-Cabó, San Celestino and Márquez. The prepatent period ranged from 31-54 days. The earliest shedding of cercariae was observed in one sample from Curupicay on the 31st day of post-exposure.

The snails from Pay-Ubre showed an index of TCP/100 of 17,494 cercariae (Class II, poorly compatible). Moreover, since the snails from Copra had the same parameters (index of TCP/100 of 13,572) they were included in the same class. Meanwhile, the other three populations from Mirungá, Aguacerito and Curupicay were not very compatible to the $\mathrm{SJ}_{2}$ strain (Class I) with an index less than 10,000 cercariae (Table). In the $B$. tenagophila controls, $42 \%$ of the exposed snails were infected (index of TCP/100 of 6.112, Class I, not very compatible). The prepatent period average was 44 days.

\section{DISCUSSION}

At the moment, foci of $S$. mansoni transmission exist in the Brazilian states bordering Northeast Argentina, but epidemiological surveys performed by previous researchers had demonstrated that natural transmission of schistosomiasis does not exist in the Río de La Plata basin of Paraguay, Argentina and Uruguay (Borda \& Rea 2007). However, B. tenagophila, that behaved as potential intermediary host of $S$. mansoni, exists in superficial waters of Yacyretá and Salto Grande dams (Borda \& Rea 1997).

The occurrence of $B$. tenagophila in irrigation channels and dam reservoirs on the Uruguay and the Miriñay River tributaries proves that the ecological changes have favoured the proliferation and dispersion of that snail. Of the five populations of $B$. tenagophila under investigation, the snails from Pay-Ubre and Copra were Class II and poorly compatible, compared to the $\mathrm{SJ}_{2}$ strain and those from Mirungá, Aguacerito, Curupicay, which were

TABLE

Susceptibility, prepatent period, cercarial output and compatibility of Biomphalaria tenagophila of 10 localities from Argentina, after exposure to $\mathrm{SJ}_{2}$ strain of Schistosoma mansoni

\begin{tabular}{|c|c|c|c|c|c|c|c|}
\hline Origin of snails & $\begin{array}{c}\text { Number } \\
\text { of exposed }\end{array}$ & $\begin{array}{c}\text { Index } \\
\text { infection }\end{array}$ & $\begin{array}{c}\text { Prepatent } \\
\text { period } \\
\text { average (days) }\end{array}$ & $\begin{array}{c}\text { Mortality in } \\
\text { precercarial period } \\
(\%)\end{array}$ & Daily average & $\begin{array}{l}\mathrm{TCP} / 100 \\
\text { index }^{a}\end{array}$ & $\begin{array}{c}\text { Class } \\
\text { description }^{b}\end{array}$ \\
\hline Itá-Cabó & 31 & 0 & - & 32.25 & - & - & 0 \\
\hline Aguacerito & 50 & 2 & 39 & 18 & 213 & 4,056 & I \\
\hline Curupicay & 81 & 2 & 31 & 22.22 & 108 & 1,407 & I \\
\hline Copra & 35 & 5.71 & 52 & 2.85 & 517 & 13,572 & II \\
\hline Pay-Ubre & 46 & 21.73 & 47 & 15.21 & 3,045 & 17,494 & II \\
\hline Yuquerí & 66 & 0 & - & 24.24 & - & - & 0 \\
\hline Mirungá 1 & 100 & 11 & 54 & 11 & 253 & 6,408 & I \\
\hline Mirungá 2 & 11 & 0 & - & 0 & - & - & 0 \\
\hline San Celestino & 10 & 0 & - & 30 & - & - & 0 \\
\hline Márquez & 10 & 0 & - & 30 & - & - & 0 \\
\hline
\end{tabular}

$a$ : duration of cercarial out put in days by daily average (total estimated); $b$ : 0 : incompatible; I: not very compatible; II: poor compatibility. 
Class I and not very compatible. The degree of compatibility between the parasite and the snail was determined to better evaluate the epidemiological importance of the species in a region free of schistosomiasis because the same susceptibility and compatibility was found in the B. tenagophila controls.

Further investigations are required for insusceptible snails from Yuquerí, Itá-Cabó, San Celestino, Mirungá 2, because few specimens were exposed to $S$. mansoni.

This paper shows for the first time that four susceptible and compatible populations were found in an area of dams of only $2500 \mathrm{~km}^{2}$ in Argentina. Although the snails were not very compatible, a risk of expansion of schistosomiasis to this area does exist given the constant movement and migration of people between endemic areas and the study area.

\section{ACKNOWLEDGEMENTS}

To Dr Wladimir Lobato Paraense, Instituto Oswaldo Cruz, Rio de Janeiro, Brazil, for S. mansoni strain, to Osvaldo Benitez, Luis Armando Mosqueda and Cristina Gené, staff of Schistosomiasis Laboratory of Cenpetrop, and to biologist Paul Smith, for assistance with the English in this paper.

\section{REFERENCES}

Borda CE, Rea MJ 1997. Susceptibilidad de Biomphalaria tenagophila de las cuencas de los ríos Paraná y Uruguay a Schistosoma mansoni. Rev Panam Salud Publica 1: 167-173.

Borda CE, Rea MJ 2007. Biomphalaria tenagophila potencial vector of Schistosoma mansoni in the Paraná River basin (Argentina and Paraguay). Mem Inst Oswaldo Cruz 102: 191-195.

Carvalho OS, Nunes IM, Caldeira RL 1998. First report of Biomphalaria glabrata in the state of Rio Grande do Sul, Brazil. Mem Inst Oswaldo Cruz 93: 39-40.

Frandsen F 1979a. Studies of the relationships between Schistosoma and their intermediate hosts. 1. The genus Bulinus and Schistosoma haematobium from Egypt. J Helminthol 53: 15-29.

Frandsen F 1979b. Discussion of the relationships between Schistoso$m a$ and their intermediate hosts, assessment of the degree of hostparasite compatibility and evaluation of schistosome taxonomy. $Z$ Parasitenkd 58: 275-296.

Graeff-Teixeira C, dos Anjos CB, de Oliveira VC, Velloso CFP, da Fonseca MBS, Valar C, Moraes C, Garrido CT, do Amaral RS 1999. Identification of a transmission focus Schistosoma mansoni in the southernmost Brazilian state, Rio Grande do Sul. Mem Inst Oswaldo Cruz 94: 9-10.

Graeff-Teixeira C, Valar C, de Moraes CK, Salvany AM, Brum CO, Maurer RL, Ben R, Mardini LB, Jobim MB, do Amaral RS 2004. The initial epidemiological studies in the low endemicity schistosomiasis area in Esteio, Rio Grande do Sul, the southernmost Brazilian state, 1997 to 2000. Mem Inst Oswaldo Cruz 99 (Suppl. I): 73-78.

Paraense WL, Corrêa LR 1989. A potential vector of Schistosoma mansoni in Uruguay. Mem Inst Oswaldo Cruz 84: 281-288.

Standen OD 1952. Experimental infection of Australorbis glabratus with Schistosoma mansoni. I. Individual and mass infection of snails and the relationship of infection to temperature and season. Ann Trop Med Parasitol 46: 48-53. 